\title{
Eksperimentasi Model Pembelajaran STAD Berbantuan Geogebra pada Materi Similaritas Ditinjau dari Gaya Belajar
}

\author{
Wawan ${ }^{1}$ \\ 1) Institut Agama Islam Ma'arif NU (IAIMNU) Metro Lampung \\ Correspondence: $\triangle$ awanwawan0215@gmail.com

\begin{tabular}{l}
\hline Article Info \\
\hline Article History \\
Received : 18-05-2017 \\
Revised : 22-05-2017 \\
Accepted : 02-06-2017 \\
\hline
\end{tabular} \\ Keywords: \\ Geogebra, Power point, \\ STAD

\begin{abstract} STAD geogebra viewed from learning style. This study used the quasi experimental research method with the factorial design of $2 \times 3$. The instruments to gather the data of the research were test of learning achievement in mathematics and student learning styles questionnaire. The data was analyzed by using the two-way analysis of variance with unbalanced cells. The conclusions as follows. (1) The cooperative learning model of STAD Geogebra type resulted in a better learning achievement in mathematics than the Powerpoint-assisted direct learning model. (2) Students with visual learning style have the same achievement with students with auditory learning styles. Students with auditory learning style have the same achievement with students with kinesthetic learning styles. Students with visual learning styles have a better academic achievement than students with kinesthetic learning styles. (3) Difference in achievement of each learning method was not consistent with their respective learning styles and differences between individual learning style also was not consistent in each learning method
\end{abstract} \\ The objective of this study was to investigate the effect of Learning model of
}

\section{PENDAHULUAN}

Sifat objek matematika yang abstrak menyebabkan matematika tidak mudah untuk dipelajari, sehingga banyak pembelajar yang merasa kesulitan belajar matematika. Ahmadi \& Supriyono [1] beberapa penyebab kesulitan tersebut antara lain pelajaran matematika tidak tampak kaitannya dengan kehidupan sehari-hari serta cara penyajian pelajaran matematika yang monoton dari konsep abstrak menuju kongkrit membuat anak tidak senang belajar matematika [2]. Berkaitan dengan hal ini, seyogyanya seorang pengajar matematika memahami bahwa setiap konsep atau prinsip matematika dapat dimengerti secara sempurna apabila disajikan kepada pembelajar dalam bentuk-bentuk kongkret. Terkait dengan hal ini, Bruner menegaskan bahwa proses internalisasi dalam belajar matematika akan terjadi dengan sungguh-sungguh (artinya proses belajar terjadi secara optimal), apabila pengetahuan yang kinestetik dipelajari oleh peserta didik tersebut difasilitasi melalui 3 (tiga) tahap yaitu Enaktif, Ikonik dan Simbolik (EIS). Memperhatikan beberapa hal tersebut menjadi sesuatu yang penting untuk mengoptimalkan proses pembelajaran pada materi-materi matematika sehingga hasil belajarnya akan maksimal [3].

Geometri merupakan salah satu cabang ilmu matematika yang mempelajari tentang titik, garis, bidang dan benda-benda ruang beserta sifat-sifatnya, ukuran-ukurannya, dan hubungannya antara yang satu dengan yang lain [4]. Banyaknya bentuk-bentuk geometri dalam kehidupan nyata menjadi salah satu 
alasan mengapa setiap pembelajar matematika wajib mempelajari materi ini. Meskipun banyak sekali materi-materi geometri yang terkait dengan kehidupan sehari-sehari ternyata tidak lantas membuat peserta didik mudah mempelajarinya. Berdasarkan beberapa penelitian yang telah dilakukan menunjukkan masih banyak pembelajar yang kesulitan dalam mempelajari materi ini. Dari penelitian Kurniasari diperoleh hasil bahwa kesalahan yang dilakukan peserta didik dari tingkat terendah sampai tertinggi adalah kesalahan abstraksi yaitu pada pengabstraksian penentuan jarak pada bidang, sudut antara garis dan bidang, kesalahan prosedural yaitu pada perhitungan bentuk akar dan penggunaan rumus phytagoras dan kesalahan konsep terjadi pada konsep jarak serta konsep sudut. Penelitian lain memberikan informasi bahwa kesulitan-kesulitan siswa meliputi: kesulitan menginterpretasi informasi dalam soal, kesulitan berbahasa, kesulitan pemahaman konsep dan prinsip dalam geometri, dan kesulitan teknis. Kesulitan dalam menyelesaikan persoalan geometri berkenaan dengan kelemahan pemahaman konsep-konsep dan prinsip-prinsip dalam geometri. Konsep-konsep dalam geometri yang tidak dikuasai peserta didik, yaitu diagonal, jarak, tinggi, segiempat, dan luas. Prinsip-prinsip dalam geometri yang tidak dikuasai peserta didik, yaitu: prinsip pengukuran garis tinggi; prinsip pengukuran jarak antara titik dan ruas garis (garis), pengukuran jarak antara dua ruas garis (garis) yang sejajar; prinsip pengukuran diagonal-diagonal segiempat; prinsip perhitungan luas segiempat. Kesulitan belajar geometri juga terjadi pada mahasiswa. Hal ini seperti disampaikan Yuliani bahwa mahasiswa kesulitan dalam memahami konsep geometri, kesulitan menerapkan konsep, kesulitan memahami rumus, dan kesulitan menentukan langkah-langkah melukis.

Materi dalam geometri merupakan salah satu materi dalam matematika yang memerlukan pemahaman khusus dan mengutamakan ketercapaian keterampilan proses, sehingga dalam mengajarkan materi ini memerlukan suatu model pembelajaran dan media pembelajaran yang tepat. Penerapan model pembelajaran dan media pembelajaran yang tepat sangat mungkin dapat memperbaiki kualitas pembelajaran pada materi ini.

Berkaitan dengan hal tersebut, penerapan model pembelajaran kooperatif dapat dijadikan sebagai bahan pertimbangan dalam memperbaiki kualitas pembelajaran. Ciri utama model pembelajaran kooperatif yakni adanya kerja sama dengan teman lain dalam mempelajari suatu materi dapat dijadikan mahasiswa sebagai sarana meningkatkan kemampuan berpikirnya dalam mempelajari matematika termasuk pada materi geometri. Hasil beberapa penelitian juga menunjukkan adanya pengaruh positif model pembelajaran kooperatif terhadap prestasi belajar mahasiswa seperti pada penelitian yang dilakukan Chin [5]. Penelitian Chin [5] yang dilakukan di Malaysia diperoleh hasil bahwa model pembelajaran kooperatif dapat meningkatkan prestasi belajar dan sikap mahasiswa terhadap matematika. Sementara dari penelitian Tran yang dilakukan di Vietnam juga diperoleh hasil bahwa pembelajaran kooperatif efektif dalam meningkatkan tingkat prestasi akademik siswa yang berpartisipasi serta dapat mempromosikan sikap positif siswa terhadap matematika. Berdasarkan pada pemikiran dan hasil-hasil penelitian tersebut, penerapan model kooperatif mungkin dapat memperbaiki sekaligus meningkatkan kualitas hasil belajar mahasiswa pada materi geometri.

Model pembelajaran kooperatif merupakan salah satu model pembelajaran yang diterapkan dengan cara berkelompok untuk bekerjasama saling membantu dalam mengkonstruksi suatu konsep serta menyelesaikan suatu persoalan-persoalan dengan tanya jawab dan diskusi. Berkaitan dengan model kooperatif tersebut, ada beberapa variasi dalam model pembelajaran ini. Slavin menyatakan tipe-tipe model pembelajaran ini antara lain: Teams-Games-Tournament (TGT), Jigsaw, Cooperative Integrated Reading 
and Composition (CIRC), Student Teams-Achievement Divisions (STAD), Team Assisted Individualization (TAI), Academic Controversy (AC), and Group Investigation (GI)[6].

Selain penerapan model pembelajaran yang tepat, penggunaan media pembelajaran yang tepat untuk mendukung penerapan suatu model pembelajaran juga dapat mengoptimalkan kemampuan berpikir. Hal ini seperti diungkapkan Arsyad yang menyatakan bahwa salah satu manfaat media pembelajaran adalah untuk meningkatkan proses dan hasil belajar[7]. Banyak mahasiswa yang kesulitan mengabstraksi konsep-konsep geometri, sehingga dengan bantuan media pembelajaran dimungkinkan mahasiswa akan lebih mudah dalam memahami konsep-konsep yang ada. Beberapa media yang bisa digunakan dalam pembelajaran pada materi-materi pada ilmu geometri antara lain Software Maple, Software Geogebra, Software Powerpoint, dan lain-lain.

Terkait dengan berbagai media tersebut, peneliti tertarik untuk mengeksperimenkan media Software Geogebra dalam pembelajaran geometri. Media berbasis aplikasi komputer ini dirasa cocok sebagai alat bantu dalam mempelajari materi-materi geometri. Penerapan media tersebut juga dirasa penting untuk menutupi beberapa kelemahan dari model pembelajaran kooperatif sehingga hasilnya benar-benar dapat mengoptimalkan prestasi belajar mahasiswa. Lebih-lebih dari beberapa penelitian juga menunjukkan hasil bahwa media berbasis komputer menghasilkan efek yang positif terhadap prestasi belajar matematika[8], [9].

Pemahaman mahasiswa pada materi geometri juga mungkin dipengaruhi oleh gaya belajar. Gaya belajar merupakan salah satu faktor internal yang di duga kuat berpengaruh terhadap prestasi belajar matematika mahasiswa. Gaya belajar merupakan cara dimana individu memproses dan mengolah informasi dalam situasi belajar. Berdasarkan pada hal tersebut, sangat dimungkinkan kecenderungan gaya belajar yang dimiliki masing-masing mahasiswa akan mempengaruhi prestasi belajarnya [10].

Berdasarkan beberapa hal yang telah diuraikan tersebut, penulis tertarik melakukan penelitian eksperimental dengan mengeksperimenkan 2 (dua) model pembelajaran secara serempak yakni model pembelajaran langsung berbantuan Power Point dan model STAD berbantuan GeoGebra. Model pembelajaran langsung berbantuan Power Point merupakan model yang sering digunakan oleh dosen dalam pembelajaran di kelas. Dengan kata lain, kelas yang dikenai pembelajaran langsung berbantuan PowerPoint merupakan kelas kontrol dalam penelitian ini.

\section{METODE PENELITIAN}

Penelitian ini dilaksanakan di dalam jangka waktu lima bulan, mulai bulan Februari 2016 sampai bulan Juni 2016. Pendekatan penelitian ini adalah kuantitatif, sedangkan metode penelitian yang digunakan adalah eksperimen semu. Rancangan penelitian yang digunakan adalah rancangan faktorial 2 x 3 [11]. Populasi dalam penelitian ini adalah seluruh mahasiswa Prodi Pendidikan Matematika IAIM NU Metro Lampung pada Semester IV Tahun Akademik 2015/2016. Teknik pengambilan sampel yang digunakan adalah cluster random sampling. Sampel pada penelitian ini berjumlah 50 mahasiswa dengan rincian 26 mahasiswa pada kelas eksperimen dan 24 mahasiswa pada kelas kontrol.

Variabel bebas dalam penelitian ini adalah model pembelajaran dan gaya belajar, sementara sebagai variabel terikatnya adalah prestasi belajar matematika. Metode pengumpulan data yang digunakan adalah metode tes, angket dan dokumentasi. Metode tes dilakukan untuk memperoleh data prestasi belajar matematika, metode angket digunakan untuk mengumpulkan data gaya belajar mahasiswa sedangkan metode dokumentasi digunakan untuk memperoleh data sampel penelitian sekaligus untuk memperoleh data kemampuan awal mahasiswa. Data kemampuan awal diambil dari 
nilai mahasiswa pada mata pelajaran Geometri hasil Ulangan Tengah Semester (UTS) I. Data inilah yang kemudian dijadikan sebagai dasar uji keseimbangan pada penelitian ini.

Instrumen yang digunakan dalam penelitian ini berupa tes dan angket yakni tes prestasi belajar matematika dan angket gaya belajar. Kedua instrumen tes tersebut sebelumnya telah diuji validitas isi dan reliabilitasnya.

Sebelum penelitian dilakukan, peneliti terlebih dahulu melakukan uji keseimbangan antara dua kelompok populasi. Statistik uji yang digunakan adalah uji $t$ [12]. Uji ini dilakukan setelah terpenuhinya persyaratan normalitas dan homogenitas variansi populasi.Selanjutnya, sesuai rancangan penelitian yang dirumuskan sebelumnya, pengujian hipotesis pada penelitian ini menggunakan anava dua jalan dengan sel tak sama. Uji ini dilakukan setelah terpenuhinya persyaratan normalitas dan homogenitas variansi populasi. Uji normalitas menggunakan metode Lilliefors, sementara untuk uji homogenitas variansi populasi menggunakan uji Bartlett [11].

\section{HASIL DAN PEMBAHASAN}

Ada empat hipotesis yang telah dirumuskan dalam penelitian ini. Pengujian untuk keempat hipotesis tersebut juga telah dilakukan dengan hasil seperti yang telah dideskripsikan sebelumnya. Berdasarkan hasil uji hipotesis tersebut, selanjutnya akan dibahas lebih lanjut mengenai keempat hipotesis yang telah dirumuskan.

Dari perhitungan dengan anava satu jalan dengan sel tak sama diperoleh $F_{a}$ sebesar 71,99 dengan daerah kritis atau $D K=\{F \mid F>4,06\}$. Hasil ini memberikan keputusan uji bahwa $H_{0 A}$ ditolak sehingga dapat disimpulkan bahwa ada perbedaan efek antar model pembeajaran terhadap prestasi belajar matematika. Dengan kata lain, tidak semua model memberikan efek yang sama terhadap prestasi belajar matematika. Meskipun $H_{0 A}$ ditolak, tidak dilakukan uji komparasi ganda karena hanya ada dua nilai untuk variabel ini. Dengan memperhatikan rerata marginalnya diperoleh kesimpulan model pembelajaran STAD berbantuan Geogebra menghasilkan prestasi belajar yang lebih baik daripada model pembelajaran langsung berbantuan PowerPoint pada mahasiswa Pendidikan Matematika IAIM NU Metro.

Hasil uji statistik tersebut kemudian digeneralisasi sebagai hasil penelitian ini yakni model pembelajaran STAD berbantuan Geogebra menghasilkan prestasi belajar yang lebih baik daripada model pembelajaran langsung berbantuan PowerPoint pada mahasiswa Pendidikan Matematika IAIM NU Metro.Hasil ini telah sesuai dengan hipotesis yang telah dirumuskan sebelumnya. Hasil ini juga sesuai dengan penelitian [5], [13], yang menunjukkan bahwa model pembelajaran kooperatif dapat meningkatkan prestasi belajar matematika serta lebih baik dari model pembelajaran konvensional. Hasil ini sekaligus melengkapi penelitian-penelitian sebelumnya terkait media berbasis komputer seperti penelitian [4], [8] yang menunjukkan hasil bahwa media berbasis komputer memberikan efek yang positif terhadap prestasi belajar matematika.

Meskipun adanya keterbatasan jumlah komputer (laptop) yang digunakan pada beberapa kelompok yakni hanya terdapat ada satu buah laptop, namun hal ini tidak mengurangi esensi penerapan model STAD yang dimodifikasi pada penelitian ini. Hal ini dikarenakan pada model STAD lebih mengutamakan kerja kelompok dibandingkan kerja individu sehingga penggunaan satu buah sampai dua buah laptop untuk setiap kelompoknya justru mewujudkan interaksi dan dinamika dalam pembelajaran sehingga pemahaman mahasiswa pada materi similaritas dapat meningkat. 
Selanjutnya, dari perhitungan dengan anava dua jalan dengan sel tak sama untuk hipotesis kedua diperoleh $F_{b}$ sebesar 24,61 dengan daerah kritis atau $D K=\{F \mid F>3,21\}$. Hasil ini memberikan keputusan uji bahwa $H_{0 B}$ ditolak sehingga dapat disimpulkan bahwa ada perbedaan efek antar tipe gaya belajar terhadap prestasi belajar matematika. Karena $H_{0 B}$ ditolak selanjutnya dilakukan uji lanjut pasca anava dengan metode Sceffe'. Dari uji lanjut diperoleh kesimpulan bahwa mahasiswa bergaya belajar visual mempunyai prestasi belajar yang sama dengan mahasiswa bergaya belajar auditorial, mahasiswa bergaya belajar auditorial mempunyai prestasi belajar yang sama dengan mahasiswa bergaya belajar kinestetik, dan mahasiswa bergaya belajar visual mempunyai prestasi belajar yang lebih baik daripada mahasiswa bergaya belajar kinestetik. Hasil tersebut selanjutnya digeneralisasi sebagai bagian dari kesimpulan pada penelitian ini.

Ada hasil yang tidak sesuai dengan hipotesis kedua yang dirumuskan dalam penelitian ini yakni hipotesis yang menyatakan bahwa mahasiswa dengan gaya belajar auditorial mempunyai prestasi belajar yang lebih baik daripada mahasiswa bergaya belajar kinestetik Hal ini dimungkinkan adanya faktor variabel luaran yang tidak bisa dikontrol oleh peneliti. Keadaan salah satu kelas yang cenderung ramai dimungkinkan menyebabkan mahasiswa bergaya belajar auditorial tidak bisa memaksimalkan kemampuannya dalam diskusi sehingga berimplikasi pada prestasi belajarnya.

Untuk hipotesis ketiga, dari perhitungan dengan anava satu jalan dengan sel tak sama diperoleh $F_{\text {obs }}$ untuk $H_{O A B}$ sebesar 21,03 dengan daerah kritis atau $D K=\{F \mid F>3,21\}$. Hasil ini memberikan keputusan uji bahwa $H_{0 A B}$ ditolak sehingga dapat disimpulkan bahwa terdapat interaksi antara model pembelajaran dan gaya belajar terhadap prestasi belajar matematika. Karena $H_{0 A B}$ ditolak maka perlu dilakukan uji lanjut pasca anava baik uji komparasi ganda antar sel pada pada kolom yang sama.

Dari uji komparasi ganda untuk hipotesis ketiga diperoleh kesimpulan bahwa: 1) Pada mahasiswa bergaya belajar visual, model STAD berbantuan Geogebra menghasilkan prestasi belajar yang lebih baik daripada model pembelajaran langsung berbantuan Powerpoint, 2)pada mahasiswa bergaya belajar Auditorial, model STAD berbantuan Geogebra menghasilkan prestasi belajar yang sama dengan model pembelajaran langsung berbantuan Powerpoint dan 3) ada mahasiswa bergaya belajar Kinestetik, model STAD berbantuan Geogebra menghasilkan prestasi belajar yang sama dengan model pembelajaran langsung berbantuan Powerpoint. Hasil tersebut selanjutnya digeneralisasi sebagai jawaban rumusan masalah ketiga yang diajukan dalam penelitian ini.

Terkait hasil ini terdapat satu hipotesis yang tidak didukung oleh data penelitian ini yakni hipotesis yang menyatakan bahwa pada mahasiswa bergaya belajar auditorial, model STAD berbantuan Geogebra menghasilkan prestasi belajar yang lebih baik dari model pembelajaran langsung berbantuan Powerpoint. Peneliti telah menganalisis semua penyebab dari tidak diterimanya hipotesis ini. Berdasarkan analisis tersebut, peneliti menduga tidak diterimanya hipotesis ini lebih disebabkan karena pengaruh variabel luaran yang tidak bisa dikontrol oleh peneliti, lebih-lebih banyaknya variabel intervening yang sangat dimungkinkan ikut mempengaruhi hasil penelitian ini.

Untuk hipotesis keempat, dari perhitungan dengan anava satu jalan dengan sel tak sama diperoleh $F_{o b s}$ untuk $H_{0 A B}$ sebesar 21,03 dengan daerah kritis atau $D K=\{F \mid F>3,21\}$. Hasil ini memberikan keputusan uji bahwa $H_{O A B}$ ditolak sehingga dapat disimpulkan bahwa terdapat interaksi antara model pembelajaran dan gaya belajar terhadap prestasi belajar matematika. Karena $H_{0 A B}$ ditolak maka perlu dilakukan uji lanjut pasca anava baik uji komparasi ganda antar sel pada pada kolom yang sama. Dari hasil uji komparasi ganda untuk hipotesis ini diperoleh kesimpulan bahwa: 1) pada model pembelajaran 
STAD berbantuan Geogebra, mahasiswa bergaya belajar visual mempunyai prestasi belajar yang sama dengan siswa bergaya belajar auditorial, mahasiswa bergaya belajar auditorial mempunyai prestasi belajar yang sama dengan siswa bergaya belajar kinestetik, dan mahasiswa bergaya belajar visual mempunyai prestasi belajar yang lebih baik daripada siswa bergaya belajar kinestetik dan 2) pada model pembelajaran langsung berbantuan Powerpoint, mahasiswa bergaya belajar visual mempunyai prestasi belajar yang sama dengan siswa bergaya belajar auditorial, mahasiswa bergaya belajar auditorial mempunyai prestasi belajar yang sama dengan siswa bergaya belajar kinestetik, dan mahasiswa bergaya belajar visual mempunyai prestasi belajar yang sama siswa bergaya belajar kinestetik.

Hasil tersebut selanjutnya digeneralisasi sebagai kesimpulan untuk hipotesis ke-empat pada penelitian ini. Dari keenam hipotesis yang menjadi bagian dari hipotesis keempat, terdapat satu hipotesis yang tidak sesuai dengan data penelitian yakni hipotesis yang menyatakan bahwa pada model pembelajaran STAD berbantuan Geogebra, mahasiswa bergaya belajar auditorial mempunyai prestasi belajar yang lebih baik daripada mahasiswa bergaya belajar kinestetik. Hasil analisis terhadap kemungkinan-kemungkinan yang menjadi penyebab hipotesis ini tidak sesuai data penelitian adalah karena adanya pengaruh variabel luaran yang tidak bisa dikendalikan oleh peneliti meskipun kemungkinan besar variabel tersebut sebenarnya dapat mempengaruhi data penelitian. Kondisi salah satu kelas yang cenderung ramai dimungkinkan menjadi faktor paling dominan mahasiswa dengan gaya belajar auditorial tidak bisa memaksimalkan diskusi pada penerapan model STAD untuk meningkatkan prestasi belajarnya. Hal ini diduga berimplikasi pada hasil belajar yang tidak optimal.

\section{SIMPULAN DAN SARAN}

Berdasarkan hasil analisis dan pembahasan diperoleh simpulan bahwa model pembelajaran STAD berbantuan Geogebra menghasilkan prestasi belajar yang lebih baik daripada model pembelajaran langsung berbantuan Powerpoint pada mahasiswa Pendidikan Matematika IAIM NU Metro. Mahasiswa bergaya belajar visual mempunyai prestasi belajar yang sama dengan mahasiswa bergaya belajar auditorial, mahasiswa bergaya belajar auditorial mempunyai prestasi belajar yang sama denganmahasiswa bergaya belajar kinestetik, dan mahasiswa bergaya belajar visual mempunyai prestasi belajar yang lebih baik daripadamahasiswa bergaya belajar kinestetik. Pada mahasiswa bergaya belajar visual, model STAD berbantuan Geogebra menghasilkan prestasi belajar yang lebih baik daripada model pembelajaran langsung berbantuan Powerpoint.Pada mahasiswa bergaya belajar auditorial, model STAD berbantuan Geogebra menghasilkan prestasi belajar yang sama dengan model pembelajaran langsung berbantuan PowerPoint.Pada mahasiswa bergaya belajar kinestetik, model STAD berbantuan Geogebra menghasilkan prestasi belajar yang sama dengan model pembelajaran langsung berbantuan Powerpoint. Pada model pembelajaran STAD berbantuan Geogebra, mahasiswa bergaya belajar visual mempunyai prestasi belajar yang sama dengan mahasiswa bergaya belajar auditorial, mahasiswa bergaya belajar auditorial mempunyai prestasi belajar yang sama dengan mahasiswa bergaya belajar kinestetikdanmahasiswa bergaya belajar visual mempunyai prestasi belajar yang lebih baik daripada mahasiswa bergaya belajar kinestetik.Pada model pembelajaran langsung berbantuan Powerpoint, mahasiswa bergaya belajar visual mempunyai prestasi belajar yang sama dengan mahasiswa bergaya belajar auditorial, mahasiswa bergaya belajar auditorial mempunyai prestasi belajar yang sama dengan mahasiswa bergaya belajar kinestetik dan mahasiswa bergaya belajar visual mempunyai prestasi belajar yang sama dengan mahasiswa bergaya belajar kinestetik. 
Mengacu pada hasil penelitian ini, diketahui model pembelajaran STAD berbantuan Geogebra menghasilkan prestasi belajar yang lebih baik daripada model pembelajaran langsung berbantuan Powerpoint. Melihat hasil ini, pengajar mapel matematika baik guru maupun dosen disarankan untuk menggunakan model pembelajaran tersebut dalam pembelajaran matematika. Penerapan model STAD berbantuan Geogebra dapat dijadikan alternatif dalam memperbaiki kualitas pembelajaran matematika. Lagipula model STAD berbantuan Geogebra cenderung mudah diterapkan di kelas. Pengajar perlu memperhatikan gaya belajar siswa maupun mahasiswa dalam pembelajaran karena dari penelitian ini diperoleh hasil bahwa masing-masing tipe gaya belajar menghasilkan efek yang berbeda terhadap prestasi belajar.

Bagi peneliti lain yang bermaksud melakukan penelitian yang sejenis perlu menambah variabel terikat lain misalnya dari ranah sikap dan atau keterampilan sehingga akan diperoleh gambaran yang lengkap mengenai hasil belajar siswa melalui model pembelajaran STAD berbantuan Geogebra. Perlu dilakukan penelitian lain tentang penerapan STAD berbantuan Geogebra pada materi maupun populasi yang berbeda. Perlu dilakukan penelitian lain terkait pengembangan model pembelajaran yang disertai media pembelajaran berbasis komputer. Beberapa media lain yang bisa digunakan dalam pembelajaran matematika antara lain software Cabri, Wingeom, Maple, Matlab, dan lain-lain.

\section{DAFTAR PUSTAKA}

[1] Ahmadi, A and Supriyono, W., Psikologi Belajar. Jakarta: Rineka Cipta, 2014.

[2] B. De Porter and M. Hernacki, Quantum Learning: Membiasakan Belajar Nyaman dan Menyenangkan. Terjemahan Ary Nilandri. Bandung: Kaifa, 1999.

[3] B. Akkoyunlu and M. Y. Soylu, "A study of Student's Perceptios in A Blended Learning Environment Based on Different Learning Styles," Educ. Technol. Soc., vol. 11, no. 1, pp. 183-193, 2008.

[4] Horton, R.M, Storm, J, and Leonard, W.H., "The Graphing Calculator as an Aid to Teaching Algebra," Contemp. Issues Technol. Teach. Educ., vol. 14, no. 2, pp. 152-162, 2014.

[5] Chin, L.C, Zakaria, E, and Daud, Y., "The Effects of Cooperative Learning on Students' Mathematics Achievement and Attitude towards Mathematics," J. Soc. Sci., vol. 6, no. 2, pp. 272$275,2010$.

[6] Slavin, R.E., Cooperative Learning: Theory, Research, and Practice. New Jersey: Prentice Hall, 2013.

[7] Arsyad, A, Media Pembelajaran. Jakarta: PT Raja Grafindo Persada, 2015.

[8] Umbaro, W.A and Saragih, H., "Meningkatkan Hasil Belajar Mahasiswa Pada Materi Ajar Similaritasdengan Menggunakan Metode Mengajar Representasi Ganda Berbantuan Maple,” 2011. .

[9] Yushau, B., "Computer Attitude, Use, Experience, Software Familiarity And Perceived Pedagogical Usefulness: The Case Of Mathematics Professors," Eurasia J. Math. Sci. Technol. Educ., vol. 2, no. 3, pp. 1-17, 2009. 
[10] Gilakjani, Visual, Auditory, Kinaesthetic Learning Styles and Their Impacts on English Language Teaching. Iran: Islamic Azad University, 2012.

[11] Budiyono, Statistika untuk Penelitian, 2nd ed. Surakarta: Sebelas Maret University Prees, 2014.

[12] Sugiyono, Metode Penelitian Pendidikan (Pendekatan Kuantitatif, Kualitatif, dan R\&D). Bandung: Alfabeta, 2013.

[13] Tarim, K and Akdeniz, F., "The Effects of Cooperative Learning on Turkish Elementary Students' Mathematics Achievement and Attitude Towards Mathematics Using TAI and STAD Methods," Educ Stud Math, vol. 67, pp. 77-91, 2008. 